\title{
Local Governance and Local Democracy in Uganda
}

\author{
John Kiyaga-Nsubuga \\ Uganda Management Institute \\ Yasin Olum \\ Makerere University, Uganda
}

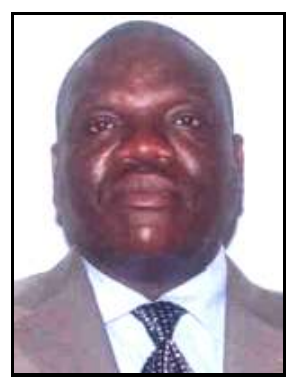

\begin{abstract}
Uganda embarked in 1993 on radical decentralization, among other reasons, to enhance local governance and local democracy. The major focus of the decentralization policy was on empowering citizens to participate in decisions that affect their localities. This issue will be examined based on two major themes of the twelve principles of the Commonwealth's 'Aberdeen Agenda' for local democracy - the enabling environment and participation. However, the paper argues that Uganda's devolutionary decentralization can only foster local governance and local democracy if it is properly conceptualised, the facilitating conditions are given careful attention, and the institutional framework is sufficiently elaborate and effective to enable it to achieve its intended objectives. Short of these measures, the gap between intent and reality might be so great as to disable the decentralization policy from achieving real local governance and local democracy.
\end{abstract}

Key words: Local governance, local democracy, Aberdeen agenda.

\section{Introduction}

Uganda embarked on radical decentralization of powers from central to local governments in the early 1990 s as a conscious strategy to enhance local 
democracy, improve service provision and reduce poverty. The initial focus was on empowering citizens to participate in decisions that affect their localities. Later, however, attention shifted to strengthening administrative systems to enable them to respond to local service delivery needs and poverty reduction imperatives. This radical shift was in response to the earlier situation in which central government had long dictated developments at local levels in an aloof manner, leaving the populace dissatisfied and unable to participate in or influence their local governance.

Because devolution of power to local levels has been quite rare in Africa, Uganda's experiment has attracted significant attention regarding the extent to which it can promote local governance and democracy, enhance service delivery and help reduce poverty. This paper examines the contribution of Uganda's decentralization to the promotion of local governance and democracy. It argues that decentralization can foster local governance and democracy at the local level if it is properly conceptualised, the facilitating conditions - especially the legal framework and citizen participation - are given careful attention, and the institutional framework is sufficiently elaborate and effective to enable it to achieve its intended objectives. Otherwise, the gap between intent and reality might be so great as to raise questions as to the extent to which decentralization can lead to real local governance and democracy.

The paper discusses these interconnected concepts in the context of the 'Aberdeen Agenda', under which twelve principles to promote local democracy and governance were adopted by the Commonwealth Local Government Conference held in Aberdeen, Scotland in 2005, and subsequently adopted by Commonwealth Heads of Government. ${ }^{1}$ Uganda's experience will be analysed based on two themes - the enabling environment, and participation and openness to attain local democracy, equity and continuous improvement - in order to illuminate the extent to which decentralization has promoted local governance and local democracy. The paper starts with an overview of 'local governance' and 'local democracy', and then proceeds to analyse how Uganda's decentralization has faired in line with the two themes.

\section{Conceptualising Local Governance and Local Democracy}

There are several ways of conceptualising local 'governance' and 'democracy'. This paper has used empirically verifiable indicators that can guide various levels of local government in determining how far they are moving along the two themes. Several tools have been developed to make such measurements, such as the UNHabitat and Transparency International Urban Governance Index (UGI) for cities

\footnotetext{
${ }^{1}$ The Aberdeen Agenda comprises twelve postulates, namely: 1. Constitutional and legal recognition of local democracy; 2. Ability to elect local representatives; 3. Partnership between spheres of government; 4. Defined legislative framework; 5. Opportunities to participate in local decisionmaking; 6. Open local government: accountability; 7. Open local government: transparency; 8. Openness to scrutiny; 9. Inclusiveness; 10 . Adequate and equitable resource allocation; 11 . Equitable service delivery; 12 . Building strong local democracy and good governance.
} 
(UN-Habitat 2004; CLGF 2004); the Local Governance Barometer (LGB) which measures local government capacity using qualitative and quantitative indicators to produce a Local Government Index (LGI) (Dufils et. al. 2006), and the Citizen Report Card or Participatory Service Delivery Assessment (Hafidh 2005) ${ }^{2}$ which is used to measure local governance and service delivery impact using feedback provided by beneficiaries to service providers.

Regardless of the tool used, it is now generally agreed that the following constitute the main attributes of good local governance: constitutionalism, rule-of-law, justice, security of person and property, electoral and participatory democracy, respect for human rights and basic freedoms, equity, citizen participation in local decision-making, effective and efficient service delivery, and transparency, accountability and integrity in the management of public and private corporate affairs (Kauzya 2002).

There is no generally agreed conceptualisation of democracy, although it is widely believed that it has intrinsic human development value and promotes individual as well as collective freedoms, responsibility for individual choices, and opportunities for citizens to protect and advance their common interests and wellbeing (Cheema and Maguire 2002). Democracy not only conditions the way in which the poor can participate in decision-making and thereby facilitate the alleviation of their conditions, it also creates space in which individuals and groups can organize along social and economic lines to pursue their interests (Webster 2000).

The concept of democracy is neither value-free nor can it be precisely or adequately defined because of differences in its interpretation by different people and classes (Novacx 1970). However, the most popular conception in current discourse is informed by liberal democracy which postulates that democracy is a system of government in which there is meaningful, extensive, regular and fair competition for all elected positions of government; a highly inclusive level of political participation; and civil and political liberties (freedom of expression, of the press, and to form and join organizations of one's choice) sufficient to ensure the integrity of political competition and participation. Democracy can also be conceived in terms of institutions, procedures, formal rights and leadership responsiveness to the electorate. These defining components of democracy are necessary in everyday practice in governmental affairs, in NGOs, and in all other human relations to ensure social order and harmony.

There is a clear connection between local democracy and local governance. Local democracy strengthens local government by creating strong, organized and representative councils to improve efficiency and responsiveness in local development. Sound local governance improves the management of political, economic, and social development at the local, community and grassroots level.

${ }^{2}$ A discussion paper of the above four instruments is provided in J. Kiyaga-Nsubuga (ed.), Local Democracy, Good Governance and Delivering The MDGS in Africa, Commonwealth Secretariat, 2007:63-66. 
Decentralization by devolution of decision-making to the lowest levels is a fundamental principle of local democracy and thereby good governance because it gives rise to a more responsive organization and greater community involvement. Conceptually, therefore, organized local bodies with clear mandates are generally more efficient and effective in enhancing local democracy and good governance, in delivering services to the local people and in reducing poverty.

\section{Assessing Local Democracy and Local Governance in Uganda}

Uganda's decentralization reforms contain an inherent paradox. On the one hand, the extent to which formal powers have been devolved from central to local levels, particularly over the management of local affairs, far exceeds what had happened in the country before and in many other African countries. On the other hand, the operation of decentralization indicates significant limitations with respect to how local governments apply those formal powers in practice. Recognizing these apparently contradictory tendencies is crucial to understanding how Uganda's decentralization process has evolved since the early 1990s. The discussion that follows will expose this fact by showing that while decentralization has deepened local democracy and governance in Uganda through the establishment of appropriate institutions, structures, and capacity, the system has not been performing as expected in some crucial areas due to lack of political will by local and national leaders to translate intent into reality.

\section{The Enabling Environment}

Uganda's local government system has a legally and constitutionally facilitating environment. It reflects devolution of powers (political, financial, personnel), functions and responsibilities to popularly elected councils and administrative units. These powers include making and implementing development plans based on locally determined priorities; making, approving and executing their own budgets; raising and utilizing resources according to their own priorities; appointing statutory committees, boards, and commissions; making ordinances and by-laws consistent with the 1995 Constitution and other existing laws, ordinances, and bylaws; hiring, managing and firing personnel; managing their own payroll and personnel systems, and implementing a broad range of decentralized services previously handled by the centre.

The system is based on the district as the primary unit, under which there are lower-level local governments (sub-county, municipal, division and town councils), and administrative units (county, parish and village). Kampala city has a separate legal status as an autonomous local government, with divisions, parishes and wards (parishes and wards are administrative units). Local governments are bodies corporate, while administrative units are not. A local government council is the highest political authority within its area of jurisdiction and has planning, administrative, financial management, budgeting, legislative and judicial powers which it exercises in accordance with the constitution, the Local Governments Act (1997) and central government policies and regulations. Local government councils 
operate through executive committees and statutory organs (District Service Commissions, District/City Contracts Committees, Local Government Public Accounts Committees).

The authoritative legislative framework on decentralization in Uganda, known as the Local Governments Act, was enacted in 1997 to consolidate and streamline the legal environment within which local governments are meant to operate. Between January 2001 and May 2006 the Act was amended ten times to respond to developments in the implementation of decentralization and to streamline local administration in the country. These numerous amendments are indicative of the steep learning curve the local government system has gone through and the flexibility of the legal framework in adjusting to changing realities. From a design standpoint, therefore, the local government system has the requisite legalconstitutional and institutional frameworks in which to operate effectively. Amending the law to address unforeseen contingencies or emerging issues is healthy, provided it does not jeopardize the operations of local governments. For example, amending the law to disband District Tender Boards (DTBs) and replace them with Local Government Contracts Committees under the control of accounting officers ${ }^{3}$ was clearly necessary because DTBs had been turned into instruments of cronyism to which people were appointed by local government councils as reward for political support after candidates have won elections. On the other hand, owing to lack of extensive analysis, considerable controversy followed the abolition of graduated tax ${ }^{4}$ in 2006 (not withstanding that it was abolished due to legitimate reasons including its regressive nature and difficulty in collection), because the resultant loss of revenue plunged local governments into a financial crisis from which they have not yet recovered (see below).

\section{Openness for Local Democracy}

\section{Citizen Participation}

Generally, Uganda's local government system is open and participative. However, there are serious challenges facing citizen participation in local development. The fact is that citizens cannot participate in public affairs, even over matters that affect them directly, unless they are empowered. 'Empowerment' refers to the political process of expanding the space for citizens to exercise their freedom of choice and action to have more control over resources and decisions that affect their lives (Deepa 2002). However, local people at the grassroots lack sufficient knowledge and organization, which exposes their agenda to the risk of 'elite capture'. A classical case of elite capture can be seen in School Management Committees (SMCs) in primary schools where the majority of the parents are poor peasants who exercise minimal control over the decision-making process, for example, in financial matters (Prinsen and Titeca 2008). It is also not easy to get the necessary

\footnotetext{
${ }^{3}$ District accounting officers, who are usually also the chief administrative officers, are responsible for receiving central government funds, dispersing them to the different departments in the district, and accounting for the use of those funds.

${ }^{4}$ Graduated tax was levied on all able-bodied adults in the country. It was paid annually and fixed by committees constituted at the different levels of local governments.
} 
information, such as services to be delivered and the funds spent on them, to local people at the right time to facilitate appropriate decision-making. Furthermore, not all ideas get included in development plans during bottom-up participatory planning, leading to unfulfilled expectations. Yet a participatory planning approach has been adopted under the provisions of section 36 of the Local Governments (Amendment) Act of 1997 that encourages involvement of all key stakeholders in development planning and implementation so that they are more responsive to the needs of the people (Republic of Uganda 2003).

A major premise upon which Uganda's local government system was built was that local citizens would participate effectively in making decisions over local development in addition to holding their leaders to account. It was also assumed that elected leaders would always work in the best interest of their electorate. The reality has turned out to be different (Francis and James 2003). In most cases citizens have little understanding of their local economies, and also find the planning and budgeting process complicated and their decisions never implemented. Practice has also shown that the local people are easily hoodwinked by unscrupulous political elites who capture the planning and budgeting process to advance their selfish interests. Although all local governments are required to publicize fiscal transfers they receive from the centre, and many of them comply, there is little evidence that local citizens across the country have all the information they need or that they are capable of analysing the financial information even if it was put at their disposal.

It is, therefore, imperative that citizens are regularly provided with adequate information on the nature and resources of local economies, and have their skills in, say, financial management, planning and budgeting enhanced so that they can sensibly participate in deciding over local plans, budgets and investments. Local governments should be assisted to develop effective communication strategies to enable this to happen.

\section{Equity}

Providing services equitably has been and still remains a major challenge to local governments in Africa in general (Kiyaga-Nsubuga 2007) and Uganda in particular. First, the cost of service delivery in Uganda has neither been established across the board nor taken into account when determining local government fiscal transfers. Instead, the deciding factor has been the amount of money that is available; which has frequently been meager. This situation is aggravated by late transfers of resources from the centre. ${ }^{5}$ Secondly, national standards of service delivery have been established only in a few social service areas, such as primary education and health. Given these limitations, local governments are finding it difficult to cope effectively with their responsibilities. It is essential, therefore, to complete the development of national standards of service delivery and link them

\footnotetext{
${ }^{5}$ Numerous instances have been reported when Local Governments have received money from the centre in the very month they are supposed to account for its utilization.
} 
to fiscal transfers, and to eliminate the problem associated with 'unfunded mandates' typical of the current arrangement.

On the positive side, service delivery has been expanded to broaden access and enhance equity. In the education sector, for example, the Universal Primary Education (UPE) programme has corrected the imbalance that existed in primary school enrolment, which largely favoured boys. ${ }^{6}$ Some special variants of the programme have targeted children who are especially disadvantaged, such as the Alternative Basic Education for Karamoja (ABEK) which targets children in the pastoral and arid Karamoja region in the north east of the country. Also, reasonably well-equipped Health Centres have been established at sub-county level, with basic drugs and well-trained doctors and health workers. Water-points have also been established within 500 meters in most rural areas (except in very remote areas) to reduce the time women spend collecting water. Local Council Courts (LCCs) have also been established at village, parish and sub-county levels to dispense local justice, because people at the grassroots were finding serious difficulties in obtaining justice through the highly bureaucratic regular court system, which they do not trust anyway. Assessments done so far indicate that LCCs have improved access to social justice by local people as compared to the regular court system whose process tends to be too complex and expensive; they are also trusted by the local people.

Society in Uganda in general is undergoing a critical transition with regard to inclusion of socially disadvantaged groups in national and local development processes. This transition is being engineered to ensure that marginalized groups are not left out with respect to allocation of authority, power and resources. The local government legal framework is very clear on this inclusion. Membership of local government councils is deliberately engineered to ensure representation of previously marginalized groups. For example, women now constitute at least $30 \%$ of every local government council; each council must also have two representatives of youth, one of whom must be female, and two representatives of the disabled, one of whom must also be female. In addition, each district has a woman representative in the national parliament. This system reflects government's desire to mobilize the formerly marginalized social groups and promote their participation in local and national decision-making.

Legislation over inclusive decision-making does not necessarily lead to equal participation of all marginalized groups in local politics. Inclusiveness and equal participation are two different things. However, although the impact of this affirmative action is yet to be established, its progressiveness is self-evident. The challenge is to give it real effect so that it can generate positive change and benefits

\footnotetext{
${ }^{6}$ In 2004 it was established that as a result of the UPE programme nationwide, levels of school enrolment of boys and girls were almost the same for the age group $6-12$ at $91 \%$. In the early $1990 \mathrm{~s}$ net primary enrolment for the same age group was estimated at about $60 \%$ with girls lagging almost 5\% behind boys. See Ministry of Finance, Planning and Economic Development (2007) "Public Service Delivery in Uganda: Abetting or Containing Inequality?" Discussion Paper No. 13, June, p. 10 .
} 
in addition to elevating the social standing of the affected groups. Increased numbers on representative bodies is of little consequence if it does not help the marginalized groups overcome the underlying bias against them in the allocation of power, social goods and services, and in values.

Fortunately, local governments have been sensitised and some councillors have been trained in mainstreaming gender issues in local development planning. Civil society organizations have played a key role in training women leaders in advocacy, negotiation and articulation. However, the ultimate test is how to ensure that all this leads to improved access to resources and services by the marginalized groups. One of the major impediments is that the resources available to local governments to provide services are too limited. While pro-poor policies have improved access to basic services such as education, health and water and sanitation nationally, the impacts show spatial variations between and within local governments. For example, in the northern region two decades of insurgency have made it impossible for people to live normal livelihoods. Even in other districts, limited resources and poor execution have prevented the benefits of local investments to be felt fully. Examples abound of shoddy construction of access roads and drainage channels, and of market and slum improvement schemes that have not made any noticeable difference. If anything, questions have been asked as to whether interventions in service delivery are making a real difference for the poor or whether they are, in fact, abetting further inequality. ${ }^{7}$

\section{Electoral Representation}

The culture of periodic elections at national and local levels has largely taken root. From the time the National Resistance Movement ${ }^{8}$ captured state power on 26 January 1986, local and national elections have been held every four years. This culture has led to turnover in local leadership which is estimated to be as high as eighty percent. Whereas this development is good for nurturing political leadership at these levels, it has also produced unintended consequences in terms of the quality of leadership and representation.

Many of those who get elected by the people turn out to be more interested in satisfying their own personal interests than those of the people who elected them. Also, as much as it would appear that every citizen above the age of eighteen is free to contest local elections, the reality is that because of the 'monetised' nature of politics in the country, many peasants can ill afford to buy their way into political office. This monetised electoral process has now taken root to the extent that even the annulment of results by the courts has not deterred those with money from buying their way into power. This elite capture of the governance process has become endemic. For example, in a study carried out by Reinikka and Svensson (Reinikka and Svesson 2004), the bulk of school grants was captured by local

\footnotetext{
${ }^{7}$ Ibid: 10 .

${ }^{8}$ Until November 2005 the National Resistance Movement was the sole political organization. Today, under the multiparty system, it is one of the political parties.
} 
officials and politicians in primary schools with impunity. The end result has been poor service provision.

Until 2006, political representation at the local level was based on the principle of 'individual merit', whereby individuals contested elected public offices on the basis of what they could offer to the local people and not on the basis of political party competition. Under the current multiparty system, however, individuals are expected to promote the agendas of their political parties rather than their personal agendas. There are two major challenges associated with this new shift in politics. First, most individuals lack sufficient experience in and knowledge of how a multiparty system works. Political parties were re-introduced in the country in November 2005 (Uganda had been ruled on a 'no party' political arrangement from 1986), and the first local, parliamentary and presidential elections based on the multiparty system were held in February and March 2006. Second, most, if not all, the political parties are not functioning in accordance with known democratic principles, values and regulations.

These political challenges have gradually influenced how local government councils operate. On the one hand, party differences have created tension in the management of local public affairs. On the other hand, some candidates have bribed their way into office using material gifts such as soap, sugar, and clothes, hoping to recoup their massive investments once in power. This buying of voters has been possible because of abject poverty across the country (up to $38 \%$ of the population is officially recognized as living in poverty). In addition, the majority of the local citizens lack adequate knowledge about their local economies to determine whether or not the candidates can realistically deliver on their promises.

The result of all this is that attendance of local council meetings has been progressively declining. There is increased perception by local people that local governments are in reality mere appendages of the central government and that most politicians get into office principally to help themselves to public resources and privileges. The latter view is reinforced by the widely reported systemic corruption at central and local government levels, resulting in the diversion of meager funds away from service provision. The other unintended consequence of corruption is that decentralization is reinforcing the power of local elites because local citizens lack 'civic competence' in the sense that they are reluctant to exercise their 'voice' and 'political agency' to effect change in their favour (GoloobaMutebi 2008).

\section{Accountability}

In Uganda, an elaborate framework is in place to ensure upward and downward accountability. However, its operation is quite problematic. Indeed, according to Blair (Blair 2000), there are important limitations on how much participation can actually deliver because accountability covers a much wider range of activity and larger scope for democratic local governance strategy than initially appears. Specifically, upward accountability is administrative in nature and is based on 
several institutions which include the Auditor-General, parliament (through its several committees, notably those on Public Accounts, Public Service, Social Services and Local Government), line ministries responsible for social services (education, health, water and sanitation, agricultural extension, and roads), the Local Government Finance Commission, local government statutory bodies (District Service Commission, Local Government Public Accounts Committees) and sectoral committees, and Resident District Commissioners (RDCs) who represent the president at the district level. RDCs play a direct watchdog role and are empowered to advise the local government chairperson ${ }^{9}$ or the Inspector General of Government (IGG) to initiate an investigation into the management of a local government council's affairs, if they consider the situation to warrant it. ${ }^{10}$ This upward accountability has been effective in improving the operations of local government in an administrative sense.

On the other hand, downward accountability has faced significant challenges. For downward accountability to be effective, political leaders should have benchmarks against which they are judged. Furthermore, the citizens should be regularly informed about how resources are being utilized and the impact arising therefrom. The citizens are supposed to be informed about this through their representatives in local government councils who scrutinize local plans, budgets and expenditures through various council committees. However, the citizens are rarely aware of these measures due to limited feedback from councillors. They also have limited means of holding the councillors to account, except perhaps during elections when their only option is either to return their councillors or to vote them out. The high turnover of councillors at local elections is indicative of pent up citizens' frustration, which could have been contained if leaders periodically provided feedback to the citizens on progress made in implementing their electoral manifestos. The limited degree of popular participation at the local levels might be the single most important explanation for the current weakness of the accountability framework.

The experience of more developed countries suggests that a vibrant civil society that is able to keep local governments in check is essential to enhance downward accountability. Because civil society in Uganda is largely weak, strengthening it would go a long way to closing this major accountability gap. Accounting mainly to central government, however effective, is insufficient.

The recent decision by government to re-centralize the appointment of local government accounting officers (chief administrative officers and town clerks) has re-ignited the debate over how the accountability issue should best be handled. Until 2006 local government accounting officers used to be under the control of local political leaders. While this was good for downward accountability, it placed the accounting officers under tremendous local political pressure to contravene established regulations and procedures, especially those relating to financial

\footnotetext{
${ }^{9}$ Chairpersons are the directly elected political heads of local governments.

${ }^{10}$ See the Local Government Act, 1997, Section 72 (2) (b) and (c).
} 
management and resources allocation. Accounting officers who resisted this pressure did so at their peril because other districts would not accept them if they were fired. Central government addressed this by re-centralizing their appointment and disciplinary procedures, principally to protect them from hostile local politicians, but this has had the unintended effect of shifting the philosophical basis of decentralization away from devolution. This conflict between philosophy and practice (and its potential consequences) is being debated widely but no consensus has yet emerged over how it should be resolved.

Accountability goes hand in hand with transparency. On transparency, there has been general improvement in the provision of information to the public on local government finance, including publication of central transfers in gazettes; public budget workshops; publication of plans, budgets and accounts; and discussion of related issues through the media. Local governments are required by the Ministry of Local Government and line ministries to publish the fiscal resources that have been transferred to them from the centre as well as those which are locally generated, and how these resources have been spent. Local government plans, budgets, accounts and accountability reports are also public documents which local people can access through their council representatives. The Freedom to Information Act also provides a legal basis for citizens to demand access to unclassified information, and local development issues are frequently covered in the media, particularly by local radio stations. Thus, in theory at least, the local government system is transparent and the citizens are expected to be well informed.

In practice, however, the reality is different. First, the primary avenue through which the citizens are supposed to be informed about decisions and investments made by their local governments is through their council representatives. To do this the council representatives must be able to travel through their constituencies to provide feedback and solicit the views of their electorate. Resources for this facilitation should come from locally generated revenue, but this source of revenue has always been inadequate and has continued to dwindle in recent years following the abolition of graduated tax. Thus, local government councillors are immobilized due to lack of these resources.

Secondly, even if ordinary citizens were supplied with all the available information on local development issues, it is doubtful if many of them would accurately interpret it due to the low literacy levels and lack of effective civic education. Lack of civic education and sensitisation on their local economies has prevented ordinary citizens from coming to grips with local development issues to demand accountability from local governments. Finally, although local citizens have been involved in developing plans for their local areas through a participatory approach, participatory budgeting has not been widely incorporated into local development processes. Thus the citizens have little idea on the efficacy of the decisions that are made on their behalf. 
The implication is that in addition to the urgent requirement for development of a national civic programme and sensitisation of citizens on the nature of their local economies, local governments need to develop effective strategies for communicating their decisions and activities to the citizens beyond those that are currently in use. The peoples' representatives should also be adequately skilled and supported to enable them to provide regular and effective feedback to their constituents. Equally importantly, civil society organizations should be strengthened to provide effective checks on local governments to ensure transparency and accountability in their operations.

\section{Scrutiny of the Executive}

Elected local government officials, comprising council members and the executive (councillors selected by the chairperson to form a 'cabinet'), have clearly defined responsibilities that provide the basis for their actions. These responsibilities include: initiating and formulating policy (with technical assistance from appointed officials) for approval by the council; overseeing the implementation of council policies by the technical staff; considering and evaluating the performance of the council at the end of each financial year against approved work plans; mobilizing people, materials and technical assistance to facilitate local development; reviewing financial reports and making appropriate recommendations to council; serving as a communication channel between central government, the district and other stakeholders; and monitoring and supervising the implementation of work plans, programmes and projects and other activities undertaken by central government, the district, local governments and NGOs in the local area.

The performance of the executive and council against this tall order is scrutinized in several ways. First, the overall performance of the local government which they are in charge of, reflects to a significant extent their effectiveness as local leaders. This performance is evaluated through technical annual assessments that are carried out by the Ministry of Local Government through its Inspectorate Department against agreed performance indicators. Local governments that meet the performance indicators are rewarded with a $20 \%$ increase in their allocation the following year, while those that fail to meet the indicators are penalized by a $20 \%$ reduction in their allocations. This mechanism has been effective in spurring local development activity and compliance with central government regulations and guidelines, and in increasing the activity level of local government councils so that their areas do not appear on the 'negative' list.

Second, the executive is scrutinized by Resident District Commissioners as explained earlier on. By monitoring the activities of local governments and advising the district Chairperson and central government appropriately, RDCs have kept many councillors on their toes. In some cases, over-enthusiasm has caused considerable tension between them and local government councils. The situation is even made worse by the apparent duplication and overlap in the roles of these public figures - the law empowers both RDCs and chairpersons to monitor the performance of local governments. 
Third, like other central and local government officials, councillors are required to conform to the Leadership Code Act (2002). They are required to submit to the Inspector General of Government (IGG - the equivalent of an ombudsman) a written declaration of their income, assets and liabilities, plus the names, income, assets and liabilities of their spouses, children and dependants, within three months of assuming office, and thereafter in March every two years. Failure to comply with this requirement may lead to their removal from office as well as further action. Although these provisions have been applied with respect to a number of high profile leaders, there is a general feeling that the office of the IGG lacks adequate capacity to enforce the Leadership Code in its entirety, and with respect to every person who falls in the leadership category in the country.

Finally, the Uganda Local Governments Association (ULGA) has developed a Charter on Accountability and Ethical Code of Conduct (Uganda Local Governments Association 2006) to enhance accountability, transparency and integrity within local governments. This is a major step forward for a system that had long been accustomed to only being regulated from the centre. Self-regulation is essential for curbing excesses and developing professionalism, and its application by local governments to themselves is an important development which portends well for the future of the system.

\section{Financing of Local Governments}

The financing of local governments has a significant bearing on local democracy and governance. If local governments raise substantial amounts of revenue from their local areas they are likely to be subjected to increased demands for downward accountability and for increased citizen participation in deciding how the resources will be used. On the other hand, the more reliant local governments are on central government for their revenue, the more likely they are to place more emphasis on upward accountability and to have less room in which to address local priorities. Given that local governments in Uganda are reliant on central government for nearly $90 \%$ of their revenue, it can be safely stated that the accountability flow is severely distorted upwards with serious implications for local level development, especially when combined with the other factors mentioned above. In fact, Steiner argues that poverty reduction through decentralization is in jeopardy in Uganda because of “... low levels of information about local government affairs, limited human capital and financial resources, restricted local autonomy, corruption and patronage, high administrative costs related with decentralization and low downward accountability" (Steiner 2007).

There are three types of fiscal transfers from central to local governments for the implementation of Uganda's decentralization policy: unconditional, conditional and equalization grants. Revenues from these sources are supplemented by locally raised revenues. 
Unconditional grants, which are determined on the basis of population (85\%) and area size $(15 \%)$, are intended to permit local governments to have considerable discretion in resource allocation in pursuit of their respective development objectives. However, local governments are required to give priority in allocation to the five Program Priority Areas (PPAs) of government, namely primary education, primary health care, agricultural extension, feeder roads, and safe and clean water. Due to consistent under-funding, however, local governments are forced to assign these grants to the wage bill.

Conditional grants, on the other hand, are meant for pre-determined programs within the PPAs, and their size, access and utilization are supposed to be the outcome of discussion between the central government and the relevant local governments. ${ }^{11}$ Conditional grants include a wage component for decentralized staff that previously belonged to the centre.

Equalization grants are a subsidy, or special provision, disbursed from the central government to the least developed local governments to enable them to meet the minimum standards of social service delivery. This grant became operational in the 1999/2000 financial year (Muduuli 1999).

Although the levels of the grants have risen significantly, there have been persistent complaints from local governments about the mismatch between the magnitude of the decentralized services local governments are burdened with, and the very limited fiscal transfers from the centre to fund those services. Another source of friction springs from the fact that the central government retains nearly two-thirds of total national tax collections even though most services are decentralized. This imbalance in resource distribution is one of the major factors behind limited service delivery at the local level.

A further source of imbalance in resource allocation springs from the allocation formula that was used when decentralization was conceived. The original design of fiscal transfers from the centre was based on the number of officers posted in each district rather than on the full personnel establishment in each district. Consequently, districts that did not have full establishments were shortchanged. This was supposed to be corrected when the districts were restructured in 2005 . However, persistent under-funding has perpetuated the imbalance. This has been made worse by continuous creation of districts; while there were 36 in 1992, by 2008 there were 82. In fact, the Minister of Local Government was recently quoted as decrying this increase in the number of districts when he stated that if this trend

\footnotetext{
${ }^{11}$ Although this requirement is stipulated in Article 193(3) of the 1995 Constitution, its breach by the Ministry of Finance, Planning and Economic Development has been a constant irritant to Local Governments; see Kiwanuka-Musisi, C.G. President, Uganda Local Authorities Association, in a paper he wrote entitled: 'Emerging Issues in the Implementation of Decentralization', a paper presented at the National Forum on the Implementation of Decentralization, held at the International Conference Centre, Kampala, Uganda, November 15 - 19, 1999:13; see also the Resolutions by the Uganda Local Authorities Association at the same forum (Resolution No. 7).
} 
continued, sooner than later every family in Uganda would be clamoring to have its own district ${ }^{12}$.

Central government fiscal transfers are supplemented by a range of local revenue sources. The 1995 Constitution empowers local governments to levy, charge, collect and appropriate fees and taxes for investment in infrastructure and service delivery. These fees and taxes include rents, rates, royalties, stamp duties, personal graduated tax, cess (a tax on local produce such as crops and animals), market dues and fees on registration and licensing. Only funds that have been budgeted for and approved by the council can be spent.

However, local revenue sources presently constitute less than $10 \%$ of total local government funding. In the rural areas, local governments used to depend mainly on graduated tax but, as noted earlier, this tax was abolished in 2006 and has been replaced by local service and hotel taxes, which local governments are yet to fully understand and implement. What this means is that local citizens have limited leverage on local governments because their contribution to local revenue is quite minimal. This indirectly undermines local democracy as it weakens downward accountability.

Local governments are also permitted to borrow through bonds, debentures or directly from commercial banks, up to $25 \%$ of locally raised revenue. However, stringent conditions are attached to discourage local governments from borrowing as follows: the Minister of Local Government must approve any borrowing exceeding $10 \%$ of what a local government may legally borrow; the local government's accounts for the previous year must have been certified by the Auditor-General; the local government must guarantee that it will meet its obligations, including salary payments, while repaying the loans; and the money borrowed must be invested in the national PPAs. No local government has borrowed money on these terms, thus suggesting that the conditions are too stringent.

\section{Conclusion}

Uganda's local government system offers prospects for enhanced local governance and local democracy. Local governance is about effective management of the totality of state and non-state activities at the local level. The involvement of civil society in the management of local development is crucial in influencing local and national government policies and promoting democracy at the local level.

Improving public service delivery and reducing poverty largely depends on the political and economic context as well as on how decentralization is designed and implemented. The conditions that are indispensable for decentralization to increase social welfare include a functioning local democracy; adequate fiscal autonomy for

\footnotetext{
${ }^{12}$ See: 'District Number Worries Otafiire', The New Vision, (Kampala), Monday September 22, 2008, p. 3.
} 
local governments; and adequate technical expertise among local and national government officials. ${ }^{13}$

In Uganda, comprehensive and robust legislation has laid an essential foundation upon which local democracy and local governance have been built. Uganda's decentralization policy and the manner in which it is being implemented has to a large extent transformed the country from what it used to be in the past where the state had nearly collapsed. There is ample evidence of local democracy and local governance in action: citizens elect their representatives in local councils; the local government system is forced to be transparent and accountable; local leaders are being made open to scrutiny; decision-making is becoming participatory and inclusive; and, to the extent possible, efforts are being made to provide services equitably.

However, there are several challenges that prevent local governments from operating to their full potential. The key challenge is the low level of civic education among the population which constrains them from participating fully in the development of their areas. Local governments are over-loaded with responsibilities in contrast to their limited capacities and the inadequate resources assigned to them. This has significant impact on peoples' perception of the extent to which local governments can solve their problems. All the challenges are intertwined, implying that addressing some requires taking action on others as well. This is to be expected considering that Uganda is undergoing socio-economic transformation that requires continuous reforms on several fronts. Further interlocking interventions, therefore, are needed to deepen local governance and local democracy so that citizens can access better services and lead better lives.

\section{References}

Blair, H. 2000. 'Participation and Accountability at the Periphery: Democratic Local Governance in Six Countries', World Development, vol. 28(1), pp. 21-39.

Brixiova, Z. 2008. 'Decentralization and Local Governance in Developing Countries: A Comparative Perspective', Comparative Economic Studies, March 2008.

Cheema, S.G. and L. Maguire, 2002. 'Democracy, Governance and Development: A Conceptual Framework', $4^{\text {th }}$ Global Forum on Re-Inventing Government, New York, US, pp. 27-33.

CLGF [Commonwealth Local Government Forum], 2005. A Democratic Audit: the state of Local Democracy in the Commonwealth, Commonwealth Local Government Handbook 2005, Publications UK.

CLGF [Commonwealth Local Government Forum], 2007. Promoting Local Democracy in Uganda: Country Report on Application of the Aberdeen Agenda in Local Governments in Uganda, November, CLGF.

Diamond, L., Linz, J.J. and S.M. Lipset (eds), 1988. Democracy in Developing Countries, vol. 2, Lynne Rienner Publishers Inc, US.

${ }^{13}$ Ibid.2. 
Dufils, J-M. et al. 2006. 'The Impact Alliance Local Government Barometer: a Tool for Strengthening MDG's Foundation; SNV. UNDP and MDP', Compendium of papers Presented at the Conference on MDG Localisation in Africa: Options and Experiences, pp. 3-4.

Francis, P. and R. James, 2003. 'Balancing Rural Poverty Reduction and Citizen Participation: The Contradictions of Uganda's Decentralization Program', World Development, vol. 31(2), pp. 325-337.

Golooba-Mutebi, F. 2008. Politics and Local Governments in Uganda, p. 153; in F. Saito (ed.), 2008. Foundations for Local Governance: Decentralization in Comparative Perspective, Physica-Verlag.

Hafidh, M. 2005. 'Participatory Service Delivery Assessment on Drinking Water and Primary Education in Zanzibar, A Pilot Citizen Report Card. A Summary of key Finding; in SNV, UNDP and MDP', Compendium of papers Presented at the Conference on MDG Localisation in Africa: Options and Experiences, Kampala, Uganda, pp. 9-11.

Kauzya, J-M. 2002. 'Local Governance Capacity Building for Full Range Participation: Concepts, Frameworks, and Experiences in African Countries', $4^{\text {th }}$ Global Forum on Re-Inventing Government, New York, United Nations, pp. 361-362.

Kiwanuka-Musisi, C.G. 1999. 'Emerging Issues in the Implementation of Decentralization', National Forum on the Implementation of Decentralization, unpublished, Kampala, Uganda.

Kiyaga-Nsubuga, J. 2007. Local Democracy, Good Governance and Delivering the MDGs in Africa: Report of the Africa Regional Symposium held in Kampala, Uganda, Commonwealth Secretariat, London, UK, pp. 57-80.

Ministry of Finance, Planning and Economic Development, 2007. 'Public Service Delivery in Uganda: Abetting or Containing Inequality?', discussion paper 13.

Muduli, M.C. 1999. 'Implications of the 1999/2000 Budget for Local Governments with Special Reference to Unconditional and Conditional Grants', National Forum on the Implementation of Decentralization, unpublished, Kampala, Uganda.

Narayan, D. (ed.) 2002. Empowerment and Poverty Reduction: A Sourcebook, World Bank, Washington D.C., p. 14.

Novacx, G. 1970. Democracy and Revolution, Pathfinder Press, New York, in M.M. Yusif, 2008. 'Local Governance and Democracy: The Basic Principles', viewed 7 January 2009, <http://mmyusuf.blogspot.com/2008/01/local-governance-and-democracy basic.html $>$.

Prinsen, G. and K. Titeca, 2008. 'Uganda's Decentralized Primary Education: Musical Chairs and Inverted Elite Capture in School Management Committees', Public Administration and Development, vol. 28(2).

Reinikka, R. and J. Svensson, 2004. 'Local Capture: Evidence from Central Government Transfer Program in Uganda', The Quarterly Journal of Economics, vol. 119, pp. 679705.

Constitution of the Republic of Uganda, 1995 (Republic of Uganda).

The Local Governments Act, 1997 (Republic of Uganda).

Republic of Uganda, 2003. Harmonized Participatory Planning Guide for Parishes/Wards, Kampala: Ministry of Local Government, p. iii. 
Steiner, S. 2007. 'Decentralization and Poverty: Conceptual Framework and Application to Uganda', Public Administration and Development, vol. 27(2), pp. 175-185.

Uganda Local Governments Association, 2006. Revised Charter on Accountability and Ethical Code of Conduct for Local Governments, Uganda Printers and Publishers Corporation, Entebbe.

UNDP [United Nations Development Programme] Somalia, 2008. 'Grassroots Democracy Strengthens Local Government in Puntland', United Nations Development Programme, 4 August 2008, viewed 7 January 2009, <http://www.reliefweb.int/rw/rwb.nsf/db900SID/KKAA-7H85D5>.

UN-HABITAT, 2004. Urban Governance in Africa: Experiences and Challenges, Urban Governance p. 3.

Webster, N. 2000. 'Democracy, Development and the Institutionalised Participation of the Poor for Poverty Reduction', in P. Collins (ed.), Applying Public Administration in Development: Guide Posts to the Future, John Wiley and Sons Ltd, Chichester, UK. 